\title{
On the Essence of Authorities Provided by Russian Federation to Interstate Association
}

\author{
Alsu Machmutovna Khurmatullina ${ }^{1} \&$ Aleksandr Fedorovich Malyi ${ }^{1}$ \\ ${ }^{1}$ Department of Constitutional and Administrative Law, Kazan Federal University, Kazan, Russia \\ Correspondence: Alsu Machmutovna Khurmatullina, Department of Constitutional and Administrative Law, \\ Kazan Federal University, 420008, Kazan, 18 Kremlyovskaya St., Russia. E-mail: akm551@mail.ru
}

Received: June 9, 2019

Accepted: August 25, $2019 \quad$ Online Published: August 31, 2019

doi:10.5539/jpl.v12n5p30

URL: https://doi.org/10.5539/jpl.v12n5p30

\begin{abstract}
The trend of interstate association development, which is actively spreading in the modern world, entails many questions that require explanation at the theoretical level. Increasingly, the issue of the state right constitutionality to participate in such associations began to be raised with the transfer of part of its authority to the associations. With the implementation of this right, the problem of preserving the sovereignty of the union state appears. These issues are considered in the article on the example of participation of the Russian Federation in the Eurasian Economic Union. In this regard, the article describes the conditions under which it is possible to transfer some part of state powers to the supranational level. Various doctrinal approaches to the study of the concept of "authority", "the authority of the Russian Federation" are also given.

The use of such research methods as comparative legal, system-structural, formal-legal allowed the author to conclude that the transfer of part of the powers of the Russian Federation to the EAEU is constitutional and the legal nature of the interstate association itself.
\end{abstract}

Keywords: authority, Russian Federation, interstate association, rights and obligations, subject matter

\section{Introduction}

Russia is a member of many interstate associations. This process is objective, because it is determined by the need to respond to the challenges of the times formed by globalization, international economic integration, and the integration of states into the world economic system. The degree of this participation is different, due to the needs of the state, and must meet the interests of its multinational people. The integrated processes with the participation of Russia are reflected most deeply in the constituent documents of the Eurasian Economic Union, the influence of conventional law about protecting the rights of citizens on the legal system of the Russian Federation are significant. All these integration processes can be carried out only on the basis of constitutional provisions and, in particular, its article 79. It provides for the possibility of the Russian Federation participation in interstate associations with the transfer of part of sovereign powers to them in accordance with an international treaty. Two conditions for the transfer of powers are established: "if this does not entail a restriction of the rights and freedoms of man and citizen and does not contradict the foundations of the constitutional system of the Russian Federation."

One can pay attention to the brevity of the constitutional norm, which inevitably gives rise to the need for its interpretation in the transfer of authority to an interstate association. Interpretation of the norm is also possible during the establishment of an interstate association, in the process of transferred right volume determination necessary for the implementation of its goals and objectives. In the process of a norm interpretation, a modification of its constitutional content is not excluded, therefore, the legislator should have clear guidelines to stay within the framework of the constitutional legal understanding. Two such guidelines are contained in the constitutional norm itself (respect for rights and freedoms, the foundations of the constitutional system), but these provisions are also quite abstract.

\section{Methods}

The method of comparative legal analysis revealed the distinctive features of the interstate association - the Eurasian Economic Union.

The use of the system-structural method of cognition made it possible to single out the conditions for the transfer of a part of state powers to interstate associations. 
The formal legal research method was used to determine the content of such concepts as "authority", "subject matter", and "rights and obligations".

\section{Results}

The participation of Russia in the establishment, creation and functioning of the Eurasian Economic Union (EAEU) gives reason to argue that the transfer of the part of the Russian Federation powers to supranational bodies of the EAEU was carried out within the framework of constitutional requirements. One cannot fail to note one feature of interstate association power development, which reflects the political component of the EAEU development rather than the legal one. The founder states approached very carefully the volume of transferred powers and limited themselves to the necessary minimum, without which the existence of an integration economic association is impossible.

\section{Discussions}

As they noted in foreign literature, supranational international organizations are transferred to state sovereignty. According to P. Pescatore, interstate associations were created in order to respond to the common needs of several states, consisting of community institutions, which are endowed with autonomy in decision-making, and are endowed with the necessary powers - normative, executive, and control, which have an effect on state and private individuals". According to L. Mallone, such organizations appear as the result of the separation of powers between Member States and the organization to which they gave part of their sovereignty.

The traditional understanding of the term "authority" is reduced to the totality of rights and obligations that, in accordance with laws, are vested in federal government bodies and other public authorities. The Constitution of the Russian Federation uses the term "the powers of the Russian Federation". It is not new to constitutional law, that its content is revealed in numerous works. However, its understanding in the context of interstate communication requires some clarification due to the fact that it has a fairly high level of abstraction. In this regard, we can talk about its essential meaning. Reflecting on the essence of the phenomenon V.E. Chirkin writes the following: "The essence makes an object or a phenomenon fundamentally different from other objects and phenomena, causes the emergence of a new term that is not complementary, developing or clarifying, but an original, basic one. Fundamental constitutional terms have such a highly generalized meaning: a person, a citizen, people, a state, a republic, a parliament, a party (political) and many others. These terms characterize the general constitutional essence". The entity has a high level of abstraction. To clarify the general essence of the concept, complementary definitions are used. "Such definitions or additions to the general term entail the appearance of other phrases, new terminological constructions with a lower (but still high) level of abstraction". Such a design is the term "the powers of the Russian Federation" with the basic defining concept of "powers".

The Constitution of the Russian Federation uses this term to denote the rights and obligations of the head of state, the State Duma, the Federation Council, the Government, the judiciary, and the prosecutor's office (The article 92, $98,99,109,114,129)$. The term "authority" is also used to designate the powers of bodies, without specifying their affiliation with a particular branch of government (Article 78), to local authorities (Article 132).

To understand the content of the general legal structure of "the Russian Federation authority", the term "authority" serves as a determining link. It focuses on the rights and obligations of the state, which may be voluminous and significant or insignificant and secondary. They can be enshrined in laws and regulations, and not necessarily reflected in the Constitution.

It should be noted that the rights and obligations are always specific, since they are vested in public authorities, and local authorities. Such powers may be transferred from one authority to another by fixing such a transfer with a regulatory legal act. It is more difficult to understand the use of the term "authority" to denote the rights and obligations of a territorial entity (state, the constituent entity of the Federation, a municipal institute).

The state does not have a specific right, since it is a legal fiction that serves to designate a territorial entity. Through the creation of a system of organs and their functioning, the state exercises legal regulation in all spheres of public life. To designate these areas, constitutional law uses the construction of "jurisdiction subjects". The Constitution of the Russian Federation distinguishes three levels of subjects of jurisdiction: the subjects of exclusive jurisdiction of the Russian Federation (Article 71), the subjects of joint jurisdiction of the Russian Federation and its subjects (Article 72), the subjects of exclusive jurisdiction of the Russian Federation subjects (Article 73). The composition of the jurisdiction subjects of the Russian Federation constituent entities is not disclosed in the Constitution, but their existence is only indicated. Within the framework of the subjects of jurisdiction, each level of the territorial organization of a federal state exercises the powers vested in the relevant authorities. Therefore, the general constitutional concept of "powers of the Russian Federation" can be interpreted as the powers 
possessed by federal state authorities, regional government bodies, and the powers of local self-government bodies.

The conclusion to the Constitution contains the provisions that may lead to the conclusion indicated above. So, in part 2 of Article 77 the following legal structure is contained: "Within the jurisdiction of the Russian Federation and the powers of the Russian Federation on the subjects of joint jurisdiction of the Russian Federation and the constituent entities of the Russian Federation, the federal executive bodies and executive bodies of the constituent entities of the Russian Federation form a single system of executive power in the Russian Federation". We draw attention to the fact that the constitutional legislator has divided two concepts - "the limits of the Russian Federation competence" and "the powers of the Russian Federation in the matters of joint jurisdiction of the Russian Federation and constituent entities of the Russian Federation". It turns out that the Russian Federation has powers "on the subject of joint jurisdiction". Thus, the powers of the Russian Federation (rights and obligations) are exercised by authorized bodies within the limits of "jurisdiction subjects".

The content of the terminological construct "the powers of the Russian Federation" is disclosed in the description that is given to the state and determines its essential content, including the content of powers that are exercised by state bodies and which can be transferred to an interstate association. For this, basic constitutional concepts ("general constitutional terms") are also used, which were enshrined in the Constitution of the Russian Federation (1993).

\section{Conclusions}

First, the delegated powers are sovereign. They are such, since they belong to the Russian Federation and the multinational people of Russia is their source (part 1, article 3; part 1, article 4).

Secondly, the transferred powers are carried out by state authorities in accordance with the Constitution and federal laws that have supremacy throughout the country (part 2, article 4; article 10; part 1, article 11).

Thirdly, the transfer of powers is possible only voluntarily, in accordance with an international treaty and subject to the conditions defined by the Constitution of the Russian Federation (p. 79).

Fourth, the legitimacy of authority transfer and the protection of its constitutionality, as well as the preservation of the principle of supremacy of the Russian Federation Constitution in the exercise of delegated powers by supranational bodies of an interstate association, is ensured by the Constitutional Court of the Russian Federation.

When they transfer the part of sovereign powers to an interstate association, the Russian Federation determines not only their composition (list), but also the volume. Assessing these qualities of delegated powers (composition, volume), it should be noted that it is impossible to provide their quantitative description. It is permissible to talk about their substantive content based on the specific situation related to the establishment of an interstate association.

For a federal state, the level of delegated powers is important that state bodies possess. First of all, these are the powers exercised by state authorities within the exclusive jurisdiction of the Russian Federation (The article 71 of the Constitution). Their transfer does not require the consent of the constituent entities of the Russian Federation. It does not require the consent of the constituent entities of the Russian Federation and the transfer of powers exercised in the joint jurisdiction of the Russian Federation and the constituent entities of the Russian Federation. It is possible to transfer to the interstate association the part of the powers exercised by the constituent entities of the Russian Federation within the scope of their exclusive jurisdiction. But this is permissible only with the consent of the constituent entities of the Russian Federation, since no one except the constituent entities of the Russian Federation (their authorities) can implement them. It should be remembered that a range of transferred competence should not put the state in the "non-returnable" dependence on the international organization. Preservation of sovereignty is provided by the possibility of revocation of the delegated powers without any conditions.

\section{Acknowledgements}

The work is performed according to the Russian Government Program of Competitive Growth of Kazan Federal University.

\section{References}

Bedjaoui, M. (1991). International Law: Achievements and Prospects. Martinus Nijhoff Publishers.

Chirkin, V. E. (2016). Constitutional terminology: monograph. M.: Norma: INFRA-M.

Ebzeev, B. S. (2017). Globalization and the emergence of transnational constitutionalism. State and Law, (1). 
Erzin, R. M. (2017). The constitutional basis for the transfer of powers of the Russian Federation to an interstate association. Dis. by the PhD in Law, Penza.

Khurmatullina, A. M., \& Malyi, A. F. (2016). THE Supranationality Problem in the Formation of Interstate Associations (The Case of the Eurasian Economic Union). Journal of Economics and Economic Education Research, 17(2), 304-309.

Malaya, T., Malyy, A., \& Nesterova, T. (2016). On the Jurisdictional Powers of the Eurasian Economic Union. Journal of Advanced Research in Law and Eco-nomics, 8(22), 2143-2147.

Malone, L. (2008). International Law. Aspen Publishers Online.

Maly, A. F., \& Erzin, R. M. (2017). About the features of the Russian Federation powers transferred to the interstate association. In S. A. Avakyan (Ed.), Constitutional law: development results, problems and prospects: the collection of materials from an international scientific conference (pp. 93-97). Moscow: RG-Progress.

Pescatore, P. (1961). Les relations extérieures des communautés européennes (Contribution a la doctrine de la personnalité des organizations internationales). RCADI.

\section{Copyrights}

Copyright for this article is retained by the author(s), with first publication rights granted to the journal.

This is an open-access article distributed under the terms and conditions of the Creative Commons Attribution license (http://creativecommons.org/licenses/by/4.0/). 